\title{
Renal and vascular effects of Crotalus durissus cumanensis venom and its crotoxin fraction
}

Pereira TP (1), Bezerra de Menezes RRPP (2), Torres AFC (1), Brito TS (2), Batista-Lima FJ (2), Vinhote JFC (2), Sousa DF (1), Ximenes RM (2), Toyama MH (3), Diz Filho EBS (4), Magalhães PJC (2), Monteiro HSA (2), Martins AMC (1)

(1) Department of Clinical and Toxicological Analyses, Federal University of Ceará, Fortaleza, Ceará State, Brazil; (2) Department of Physiology and Pharmacology, Federal University of Ceará, Fortaleza, Ceará State, Brazil; (3) São Paulo Experimental Coast Campus, São Paulo State University (UNESP - Univ Estadual Paulista), São Vicente, São Paulo State, Brazil; (4) Department of Biochemistry, State University of Campinas, Campinas, São Paulo State, Brazil.

\begin{abstract}
In this study, we evaluated the actions of Crotalus durissus cumanensis venom (CDCmV), and its crotoxin (Crtx) fraction, on renal and vascular functions in Wistar rats. In isolated perfused kidneys, CDCmV $(10 \mu \mathrm{g} / \mathrm{mL})$ significantly increased the perfusion pressure (PP) from $110.7 \pm 2.4$ to $125.3 \pm 2.8 \mathrm{mmHg}$ after 30 minutes. This effect was accompanied by an increased renal vascular resistance (RVR) from $5.4 \pm 0.1$ to $6.2 \pm 0.2 \mathrm{mmHg} / \mathrm{mL} \cdot \mathrm{g}^{-1} \cdot \mathrm{min}^{-1}$. We observed decreases in urinary flow (UF) from $0.13 \pm 0.01$ to $0.05 \pm 001$ $\mathrm{mL} \cdot \mathrm{g}^{-1} \cdot \mathrm{min}^{-1}$ and glomerular filtration rate (GFR) from $0.66 \pm 0.06$ to $0.18 \pm 0.02 \mathrm{~mL} \cdot \mathrm{g}^{-1} \cdot \mathrm{min}^{-1}$. Crtx did not change PP or RVR, but diminished GFR (from $0.65 \pm 0.05$ to $0.26 \pm 003 \mathrm{~mL} \cdot \mathrm{g}^{-1} \cdot \mathrm{min}^{-1}$ ) and UF (from $0.11 \pm$ 0.008 to $0.09 \pm 0.008 \mathrm{~mL} \cdot \mathrm{g}^{-1} \cdot \mathrm{min}^{-1}$ ). Both $\mathrm{CDCmV}$ and $\mathrm{Crtx}$ reduced the percentage of tubular transport of sodium, chloride and potassium. The cytotoxicity of these substances against MDCK cells was tested by the MTT method: only CDCmV caused a decrease in the cell viability with an $\mathrm{IC}_{50}$ of $5.4 \mu \mathrm{g} / \mathrm{mL}$. In endothelium-intact isolated aortic rings, $C D C m V(0.1$ to $30 \mu \mathrm{g} / \mathrm{mL})$ increased the sustained phenylephrineinduced contraction to a value of $130.0 \pm 6.6 \%$ of its corresponding control, but showed a relaxant effect in endothelium-denuded preparations. Similar results were observed in aortic rings contracted with potassium $(40 \mathrm{mM})$. Crtx was ineffective in aortic ring assays. Thus, it is reasonable to suggest that the renal effects induced by the $C D C m V$ may be due to its influence on the endothelium's ability to release factors that can alter the contractile behavior of vascular smooth muscle. In conclusion, CDCmV is toxic to kidney cells. It changes parameters of the renal function including the glomerular filtration rate, renal vascular resistance and tubular transport. The actions induced by $C D C m V$ also involve endothelium-dependent vasoactive properties. Their effects may be only partially attributed to $\mathrm{Crtx}$.
\end{abstract}

Key words: kidney, vascular injuries, Crotalus durissus cumanensis, crotoxin.

\section{INTRODUCTION}

Ophidian accidents represent an important cause of morbidity and mortality in tropical countries (1). The rattlesnake Crotalus durissus has a widespread distribution in South and Central America, where 14 subspecies have been described (2). Accidents involving species of the genus Crotalus are usually serious and frequently fatal in the absence of specific and adequate treatment, mainly due to acute renal failure $(3,4)$.
It has been shown that crotalic venom provokes neurotoxicity, coagulation disorders, systemic myotoxicity and acute renal failure, which can be attributed to the venom's ability to either directly affect the glomerular and tubular cells or indirectly cause the release of vasoactive mediators (46). Snake venom may also contain toxins that have profound cardiovascular effects $(7,8)$. For instance, we have previously demonstrated the hypotensive effects of a natriuretic peptide isolated from Crotalus durissus casacavella venom (9). 
Crotalus durissus cumanensis (CDCm) is a snake found in Venezuela and northern Brazil, and its venom contains enzymes and toxins such as crotoxin, crotamine, gyroxin and convulxin $(10,11)$. Crotoxin, the major component of the $C$. d. cumanensis venom $(\mathrm{CDCmV})$, is responsible for most of its neurotoxic and myotoxic effects $(6,12)$. This toxin occurs in several isoforms and is composed of two subunits, one with phospholipase $\mathrm{A}_{2}$ activity and the other known as crotapotin (Crpt) isoform $(13,14)$. A few studies have reported the effects of the $\mathrm{CDCmV}$ on the cardiovascular system $(6,15)$. It has also been observed that envenomated patients display respiratory paralysis with potential development of renal dysfunction (16). Thus, given the persistent scarcity of studies regarding the pathophysiology of the effects caused by this venom, the present work was undertaken to investigate the renal and vascular effects induced by $\mathrm{CDCmV}$ and its major fraction, crotoxin.

\section{MATERIAL AND METHODS}

\section{Venom and Reagents}

The CDCmV was purchased from the BioAgents Serpentarium (municipality of Batatais, São Paulo, Brazil). Reagents, salts and solvents, all of analytical purity, were purchased from various suppliers including Bio Rad (USA), Sigma (USA), Boehringer Mannhein (Germany), Aldrich (USA) and Applied Biosystems (USA).

\section{Animals}

Male Wistar rats (250-350 g, $\mathrm{n}=31$ ) were maintained under standard conditions of temperature and humidity with standard 12-hour light/dark cycles. Food and water were provided ad libitum. The experiments were conducted with prior approval from the Ethics Committee on Animal Research of the Federal University of Ceará (protocol n. 68/08).

\section{Isolation and Purification of Crotoxin}

The whole venom was firstly fractionated as described by Diz Filho (17). Briefly, the dried venom (45 mg) was completely dissolved in ammonium bicarbonate buffer (0.2 M, pH 8.0) and then submitted to centrifugation $(4500 \mathrm{~g}$ for one minute) for clarification. The supernatant obtained was recovered and injected onto a size-exclusion HPLC column (Superdex $75^{\oplus}, 1 \times 60 \mathrm{~cm}$, Pharmacia, USA) previously equilibrated with the same buffer used for dissolving the whole venom. The flow rate used for elution of the fraction was $0.2 \mathrm{~mL} /$ minute. The chromatography was monitored at $280 \mathrm{~nm}$ and the crotoxin-like fraction was immediately lyophilized. The purity of the resulting crotoxin was evaluated by Tricine sodium dodecyl sulfate polyacrylamide gel electrophoresis (SDS-PAGE). The chromatographic data were processed by the software package Millennium ${ }^{\circledast}$ (Waters Inc, USA) that allowed the manual integration of each fraction and estimation of the purified crotoxin concentration.

\section{Measurement of Secretory Phospholipase $A_{2}$ Activity}

The secretory phospholipase $\mathrm{A}_{2}$ activity $\left(\mathrm{sPLA}_{2}\right.$ ) was measured according to the protocol described by Toyama et al. (18) for a 96-well plate. The standard assay mixture contained 200 $\mathrm{mL}$ of buffer $\left(10 \mathrm{mMTris}-\mathrm{HCl}, 10 \mathrm{mM} \mathrm{CaCl}_{2}\right.$, $100 \mathrm{mM}$ and $\mathrm{NaCl}, \mathrm{pH} 7.8$ ), $20 \mu \mathrm{L}$ of substrate [4-nitro-3-octanoyloxy-benzoicacid (4N3OBA) manufactured by Biomol, USA], $20 \mu \mathrm{L}$ of water and $20 \mu \mathrm{L}$ of $\mathrm{PLA}_{2}$ to yield a final volume of $260 \mu \mathrm{L}$. Enzyme activity, expressed as the initial reaction velocity $\left(\mathrm{V}_{0}\right)$, was calculated based on the increase in absorbance after 20 minutes. The effect of substrate concentration on enzyme activity was determined by measuring the absorbance increase after 20-minute incubation in Tris- $\mathrm{HCl}$ buffer, $\mathrm{pH} 8.0$, at $37^{\circ} \mathrm{C}$. All assays were done using $\mathrm{n}=12$ and the absorbances at $425 \mathrm{~nm}$ were measured using a SpectraMax $340^{\circ}$ multi-well plate reader (Molecular Devices, USA).

\section{Mass Spectrometry and Size Exclusion HPLC}

The electrospray tandem mass spectrometry (ES-MS/MS) of the crotoxin complex was analyzed according to the method described by Toyama et al. (19). Essentially, sample analysis was performed via an electrospray tandem mass spectrometer (model QUATRO II Triple Quadrupole $^{\varpi}$, Micromass Ltda., UK). The proteins were dissolved in the mobile phase of aqueousacetonitrile solution (1:1) and injected into the source at a flow rate of $5 \mu \mathrm{L} /$ minute. The mobile phase was acidified with $0.5 \%$ formic acid for the experiments in the positive mode. Experiments in the negative mode were conducted with a mobile phase of water and propanol (1:1) with 
$1 \%$ ammonium hydroxide. Samples were diluted to reach concentrations of $20-30$ pmoles $/ \mu \mathrm{L}$. The tuning parameters for the protonated molecular ions of the purified crotoxin were optimized to provide a resolution of $2 \mathrm{Da}$ at half the peak height. MCA acquisition was programmed by scanning MS1 over the mass range from 1100 to $2500 \mathrm{~m} / \mathrm{z}$ at $10 \mathrm{~s} / \mathrm{scan}$ with an interscan delay of $0.1 \mathrm{~s}$. Ten scans were obtained for each analysis. The instrument was calibrated with bovine serum albumin (BSA) over the range from 900 to 2500 $\mathrm{m} / \mathrm{z}$ as described in the instrument's manual for scanning and static modes. All protein spectra acquired in negative and positive MS were analyzed using MASSA-LINX software.

The size exclusion HPLC was done according to the protocol described by de Oliveira et al. (20). Briefly, $0.5 \mathrm{mg}$ of isolated sPLA $\mathrm{A}_{2}$ or isolated Crpt and PLA 2 :Crpt (1:1, w:w) mixture was dissolved in $0.2 \mathrm{~mL}$ of $0.05 \mathrm{M}$ phosphate buffer, $\mathrm{pH} 7.5$, and applied to a Protein-Pack TSK gel 3000 column $(0.8 \mathrm{~cm} \times 30 \mathrm{~cm})$ previously equilibrated with the same buffer. All samples were pre-incubated for 30 minutes in phosphate buffer. Separately, molecular mass markers (BSA - $66 \mathrm{kDa}$; egg albumin $-45 \mathrm{kDa}$; carbonic anhydrase $-29 \mathrm{kDa}$, and lysozyme $-14 \mathrm{kDa}$ ) were used to estimate the molecular weight of sPLA ${ }_{2}$, Crtp and the $\mathrm{PLA}_{2} /$ Crtp mixture. All molecular weight markers were dissolved in phosphate buffer at a concentration of $2 \mathrm{mg} / \mathrm{mL}$. The proteins were eluted at a flow rate of $0.2 \mathrm{~mL} /$ minute and the absorbance profile was monitored at $214 \mathrm{~nm}$.

\section{Isolated Perfused Kidney Preparation}

Rat kidneys were isolated and perfused according to the method described by Bowman (21). First, the rats were anesthetized with sodium pentobarbital (50 mg/kg, intraperitoneally). The abdomen was opened through a midline incision, and the right kidney was exposed. After careful dissection of the kidney, the renal artery was cannulated via the mesenteric artery without interrupting blood flow. The perfusate solution consisted of a modified Krebs-Henseleit solution (MKHS) with the following composition in $\mathrm{mmol} / \mathrm{L}: 118.0 \mathrm{NaCl}, 1.2 \mathrm{KCl}, 1.18 \mathrm{KH}_{2} \mathrm{PO}_{4}$, $1.18 \mathrm{MgSO}_{4} .7 \mathrm{H}_{2} \mathrm{O}, 2.50 \mathrm{CaCl}_{2} .7 \mathrm{H}_{2} \mathrm{O}$ and 25.0 $\mathrm{NaHCO}_{3}$. Six grams of bovine serum albumin (BSA) was added to $100 \mathrm{~mL}$ of MKHS and dialyzed for 48 hours at $4^{\circ} \mathrm{C}$ against ten volumes of MKHS. Immediately before the beginning of each perfusion protocol, $100 \mathrm{mg}$ of urea, $50 \mathrm{mg}$ of inulin and $50 \mathrm{mg}$ of glucose were added to every $100 \mathrm{~mL}$ of perfusate, and the $\mathrm{pH}$ was adjusted to 7.4. In each experiment, $100 \mathrm{~mL}$ of MKHS was re-circulated for 120 minutes. Perfusion pressure (PP) was measured at the tip of a stainless steel cannula in the renal artery. Samples of urine and perfusate were collected at ten-minute intervals for the determination of sodium, chloride and potassium levels by means of ion-selective electrodes (Rapid Chem $744^{\circ}$, Bayer Diagnostic, UK). Inulin was determined by direct hydrolysis, as described by Walser et al. (22). Osmolality was measured by a vapor pressure osmometer (5100C ${ }^{\oplus}$, Wescor, USA). The CDCmV $(10 \mu \mathrm{g} /$ $\mathrm{mL})$ or crotoxin $(10 \mu \mathrm{g} / \mathrm{mL})$ was added to the system just after the basal perfusion pressure had stabilized (30 minutes after the beginning of each experiment). Perfusion pressure (PP), renal vascular resistance (RVR), urinary flow (UF), and glomerular filtration rate (GFR) were evaluated. Urine and perfusate samples were collected at 30-minute intervals to evaluate the percentage of tubular transport for $\mathrm{Na}^{+}\left(\% \mathrm{TNa}^{+}\right), \mathrm{K}^{+}\left(\% \mathrm{TK}^{+}\right)$ and $\mathrm{Cl}^{-}\left(\% \mathrm{TCl}^{-}\right)$as determined by MartinezMaldonado and Opava-Stitzer (23).

\section{Cytotoxicity Assay}

\section{MTT assay}

Epithelial Madin-Darby canine kidney (MDCK) cells were cultured in RPMI-1640 medium, supplemented with fetal bovine serum (FBS - 10\%), penicillin $(100 \mathrm{U} / \mathrm{mL})$, and streptomycin $(100 \mu \mathrm{g} / \mathrm{mL})$. Cells were seeded at a concentration of $1 \times 10^{5}$ cells $/ \mathrm{mL}$ on microplates, and incubated at $37^{\circ} \mathrm{C}$ with $5 \% \mathrm{CO}_{2}$ for two hours. After cells were washed with sterile phosphate buffered solution (PBS) at $\mathrm{pH} 7.4$, they were treated with $\mathrm{CDCmV}$ or crotoxin (3.12, $6.25,12.5,25,50$ or $100 \mu \mathrm{g} / \mathrm{mL}$ ) for 24 hours and then evaluated using an inverted microscope. The negative control was prepared with medium plus cells and PBS instead of venom. The plates were incubated for 24 hours; the cell supernatants were removed and 3-(4,5-dimethythiazol-2-yl)-2,5 diphenyltetrazolium (MTT) $(500 \mu \mathrm{g} / \mathrm{mL}$ in PBS; Sigma, Brazil) was added to each plate well (20 $\mu \mathrm{L} /$ well). The method is based on the reduction of tetrazolium salt by active mitochondria in living cells to insoluble purple formazan crystals (24). After incubation for four hours at $37^{\circ} \mathrm{C}$ in 
$5 \% \mathrm{CO}_{2}$, the supernatant was removed and $10 \%$ SDS in $\mathrm{HCl} 0.01 \mathrm{~N}$ was added to solubilize the formazan crystals. The plates were incubated for 17 hours and the absorbance was then measured spectrophotometrically at $570 \mathrm{~nm}$. The assays were performed as three independent experiments in triplicate. Cell viability was determined by evaluating the mean percentage of surviving cells at a given venom or crotoxin concentration. Survival measured in the negative control was taken to be equal to $100 \%$.

\section{Isolated Aorta Assay}

Rats were sacrificed by cervical dislocation and the thoracic aorta of each animal was removed and immersed in perfusion medium at room temperature. After removing the adhering fat and connective tissue, the aorta was cut transversely into cylindrical strips $(1 \mathrm{x} 5 \mathrm{~mm})$, which were suspended in a $5 \mathrm{~mL}$ organ bath containing continuously aerated perfusion solution (136 $\mathrm{mMNaCl}, 5.0 \mathrm{mMKCl}, 0.98 \mathrm{mM} \mathrm{MgCl}, 2.0 \mathrm{mM}$ $\mathrm{CaCl}_{2}, 0.36 \mathrm{mM} \mathrm{NaH}_{2} \mathrm{PO}_{4}, 11.9 \mathrm{mM} \mathrm{NaHCO}_{3}$ and $5.5 \mathrm{mM}$ glucose $)$ at $37^{\circ} \mathrm{C}(\mathrm{pH}=7.4)$. Aortic rings were stretched with a passive tension of $0.5 \mathrm{~g}$ and tension was recorded via an isometric transducer (Grass Model FTO3 ${ }^{\circledR}$, USA) connected to a PCbased data acquisition system (PM-1000 ${ }^{\oplus}$, CWE Inc., USA). After an equilibration period of at least 60 minutes, control contractions were induced by adding $60 \mathrm{mM}$ potassium chloride to the bath. When two successive control contractions showed similar amplitude, preparations were considered equilibrated. In order to assess the vasorelaxant effects, aortic ring preparations were contracted with either phenylephrine (PHE, $0.1 \mu \mathrm{M})$ or potassium $(40 \mathrm{mM})$. The $\mathrm{CDCmV}$ $(0.1-30 \mu \mathrm{g} / \mathrm{mL})$ or crotoxin $(0.1-30 \mu \mathrm{g} / \mathrm{mL})$ was cumulatively added over a period of five minutes once a sustained contraction elicited by PHE or potassium was established.

In order to examine whether the vascular activity of the venom is dependent on the endothelial integrity, the vasorelaxant effects of $\mathrm{CDCmV}$ were determined in preparations without functional endothelium. The endothelium was removed by gentle rubbing of the aortic intimal surface with a stainless steel wire. Each endothelium-containing or endotheliumdenuded preparation was challenged at the beginning of the experiment with $1 \mu \mathrm{M}$ of acetylcholine, which was applied after the establishment of a stable plateau of potassium (30 mM)-induced contraction. The removal of endothelium was considered successful when no relaxation was observed after the addition of acetylcholine (25). Afterwards, a cumulative concentration-response curve was constructed for CDCmV (0.1-50 $\mu \mathrm{g} / \mathrm{mL})$. Data are expressed as the contraction percentage measured in the absence of CDCmV.

The vasorelaxant effects elicited by $\mathrm{CDCmV}$ were also studied under $\mathrm{Ca}^{2+}$-free conditions. The $\mathrm{Ca}^{2+}$-free medium was prepared by omitting $\mathrm{CaCl}_{2}$ from the normal solution and adding $2 \mathrm{x}$ $10^{-5} \mathrm{M}$ ethylene glycol bis-(2-aminoethyl ether)N,N,N'N-tetraacetic acid (EGTA). Calcium availability from extracellular medium was evaluated by recording the contraction induced by $\operatorname{PHE}(0.1 \mu \mathrm{M})$ in $\mathrm{Ca}^{2+}$-free medium. After an equilibration period (60 minutes) in normal $\mathrm{Ca}^{2+}$-containing solution, endothelium-intact preparations were washed three times in $\mathrm{Ca}^{2+}$-free medium (with EGTA) and then challenged with $0.1 \mu \mathrm{M}$ PHE after three minutes, a procedure that produced a small and transient contraction. In order to replace intracellular calcium stores, the tissue was washed with normal $\mathrm{Ca}^{2+}$-containing solution, followed by the administration of 0.1 $\mu \mathrm{M}$ PHE. The tissue was washed three times in $\mathrm{Ca}^{2+}$-free medium, $\mathrm{CDCmV}(30 \mu \mathrm{g} / \mathrm{mL})$ was added to the preparations for three minutes and, finally, a second contraction was induced by PHE. The PHE-induced contraction obtained in the absence of $\mathrm{CDCmV}$ was defined as $100 \%$.

\section{Statistical Analysis}

Statistical analysis was done using one-way ANOVA followed by the Bonferroni or Dunnett post-tests with the significance level set at $p<$ 0.05 , or one-way ANOVA followed by the HolmSidak post-test, with $p<0.01$. The $\mathrm{IC}_{50}$ was defined as the venom concentration resulting in $50 \%$ cell viability as estimated by interpolation between the mean percentages of dead cells and venom concentrations, and was obtained by non-linear regression analysis.

\section{RESULTS}

\section{Isolation and Purification of Crotoxin from the CDCmV}

The molecular exclusion chromatographic profile of $\mathrm{CDCmV}$ revealed the presence of 
crotoxin (fraction III) and crotamine (fraction IV) as the major components of the whole venom. Crotoxin and crotamine appear to account for approximately $40 \%$ and $35 \%$ of the dried venom, respectively (Figure $1-A$ ). In
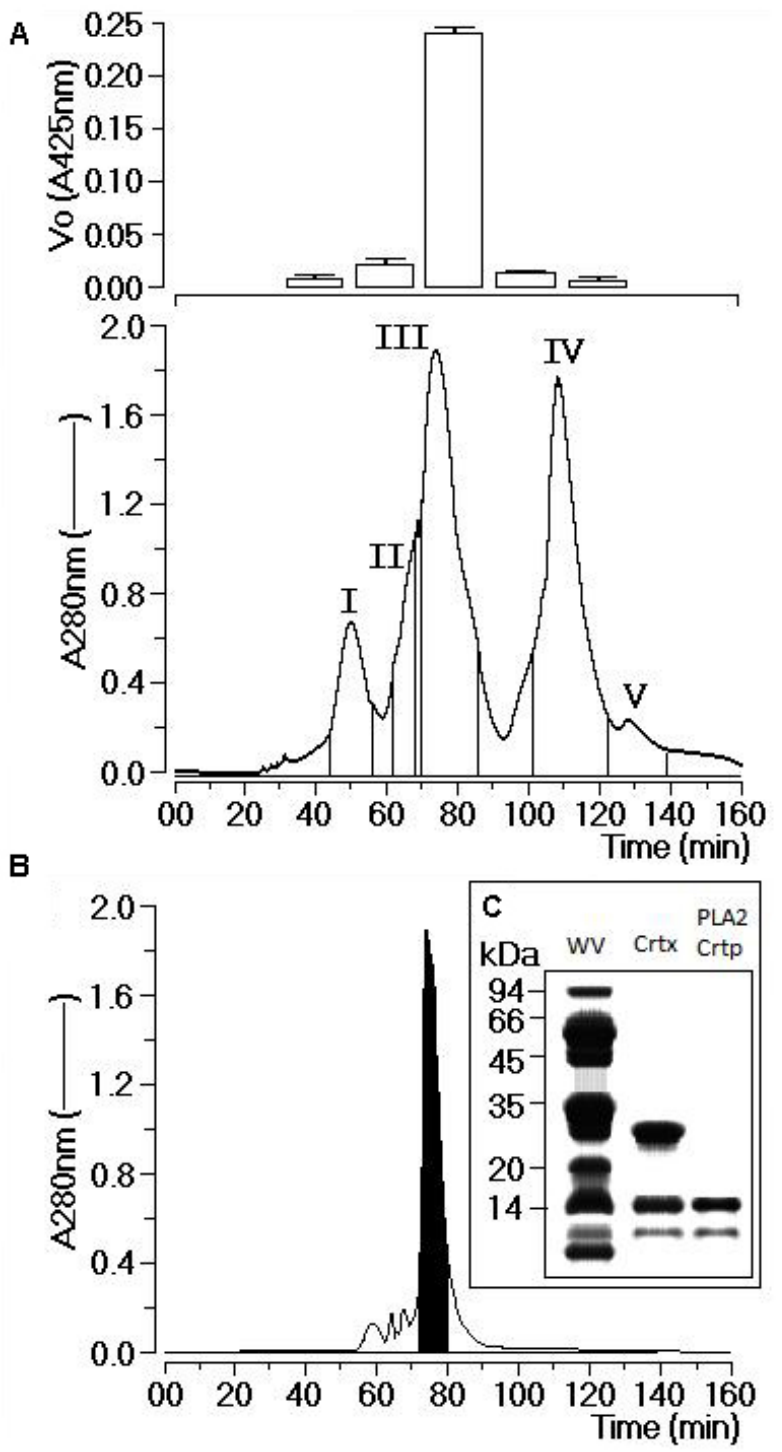

Figure 1. (A) The fractionation of whole venom, which is injected onto the molecular size exclusion HPLC column. The chromatographic run was monitored at $280 \mathrm{~nm}$ and aliquots of the main fraction were collected to monitor enzymatic activity. Under this condition, we found that fraction III showed the main PLA 2 activity. The fractions I, II and IV were identified as convulxin, gyroxin and crotamine, respectively. (B) The purification of crotoxin fraction from the fraction III, the highly purified crotoxin appears as the black peak. (C) The electrophoretic profile of whole venom (WV), highly purified native crotoxin and crotoxin after reduction with $1 \mathrm{MDTT}$.
Figure 1 - B, the crotoxin-fraction purification is displayed followed by the Tricine SDS-PAGE analysis (Figure $1-\mathrm{C}$ ). The crotoxin exhibited two monomers, one with molecular mass of approximately $14 \mathrm{kDa}$ and another with $9 \mathrm{kDa}$, as shown by SDS-PAGE in Figure $1-C$. The evaluation of the enzymatic activity from different $\mathrm{CDCmV}$ fractions revealed that the major $\mathrm{PLA}_{2}$ activity was found in the crotoxin portion because it produced the highest $\mathrm{V}_{0}$ value at $425 \mathrm{~nm}(0.243$ $\pm 0.085 ; \mathrm{n}=12$ ) (Figure $1-\mathrm{A}$ ).

Analysis of crotoxin on the ES-MS/MS revealed the presence of two main fractions, Crpt and sPLA ${ }_{2}$, with respective molecular masses of $9.64 \mathrm{kDa}$ and $14.65 \mathrm{kDa}$, and two additional peaks of 25.50 and $29.30 \mathrm{kDa}$. These results showed a strong correlation with the electrophoretic profile observed for crotoxin, given that the dimer formed by association of crotapotin and SPLA has a molecular mass of $25.50 \mathrm{kDa}$ as confirmed by the third FLPC peak. On the other hand, since sPLA 2 presented a molecular mass of $14.65 \mathrm{kDa}$, the fraction with a molecular weight of 29.30 may reflect an interaction of two $\mathrm{SPLA}_{2}$ peaks (Figure 2 - A). The molecular exclusion HPLC profile of sPLA $_{2}$ :Crtp, sPLA ${ }_{2}$ and Crpt is shown in Figure $2-\mathrm{B}$. The chromatographic $\mathrm{PLA}_{2}$ profile revealed two main fractions, one representative of a monomeric form of $\mathrm{PLA}_{2}$ and the other of a $\mathrm{PLA}_{2}$ homodimer. Isolated Crpt showed a molecular mass estimated at $30 \mathrm{kDa}$. The results from this type of chromatography of the native Crotapotin strongly suggested a self-association of the three molecules of the Crtp, while the mixture of Crpt and $\mathrm{PLA}_{2}$ produced several peaks in the molecular weight range from 10 to $30 \mathrm{kDa}$ (Figure $2-\mathrm{B})$. Thus it is possible that native crotoxins may be composed of several peaks from 14 to $30 \mathrm{kDa}$, which represent a different and random association of sPLA ${ }_{2}$ and Crpt units.

\section{Effects of CDCmV and Crotoxin in Isolated Rat Kidney Assay}

All renal parameters obtained after perfusion of isolated rat kidneys with MKHS remained stable for 120 minutes under controlled conditions. As can be seen in Figure 3, the infusion of CDCmV $(10 \mu \mathrm{g} / \mathrm{mL}, \mathrm{n}=6)$ into the perfusion solution of the isolated perfused rat kidney produced a significant increase $(p<0.05$, Bonferroni) in both perfusion pressure (PP, Figure $3-A)$ and renal vascular resistance (RVR, Figure $3-B)$ values at 


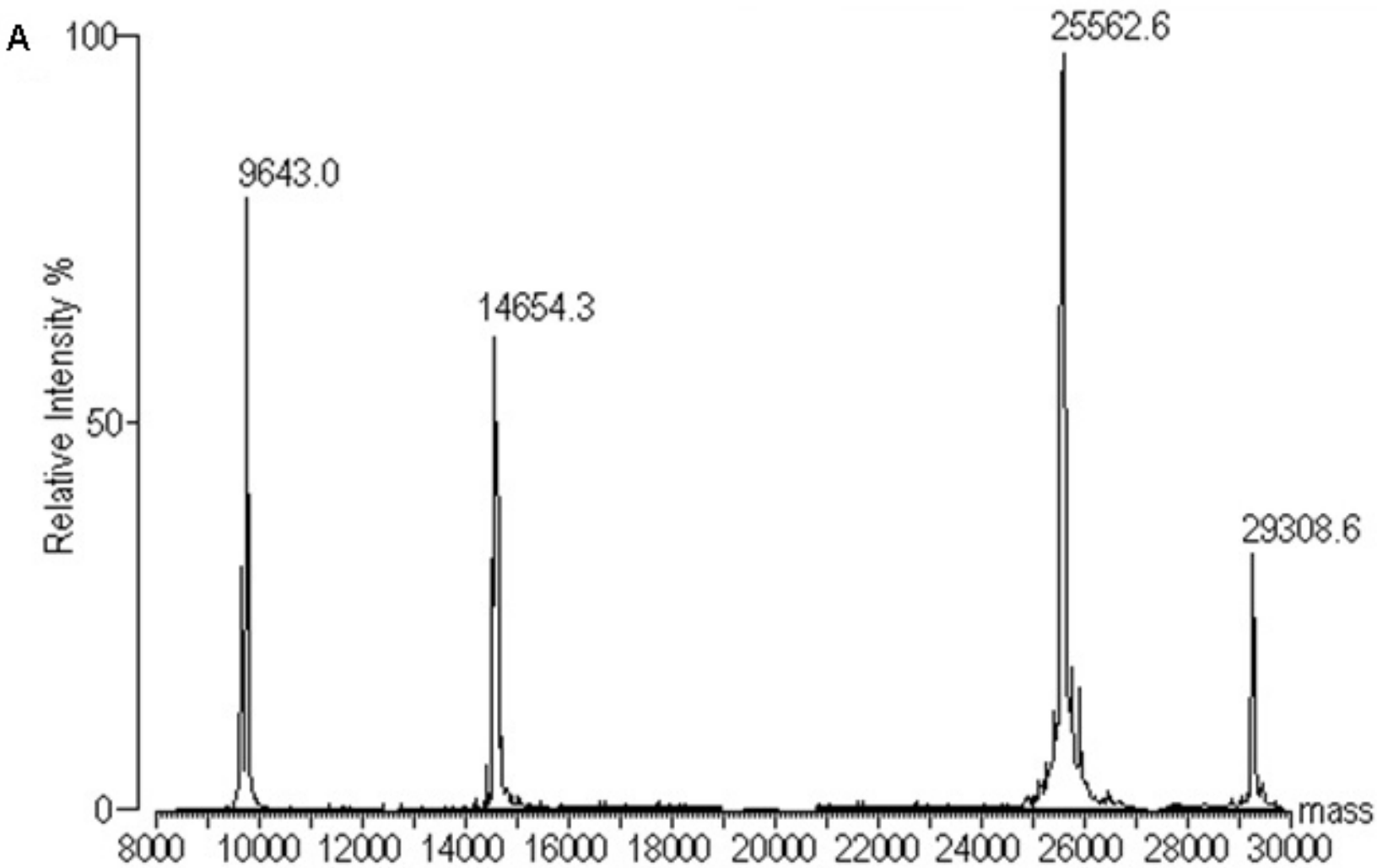

B

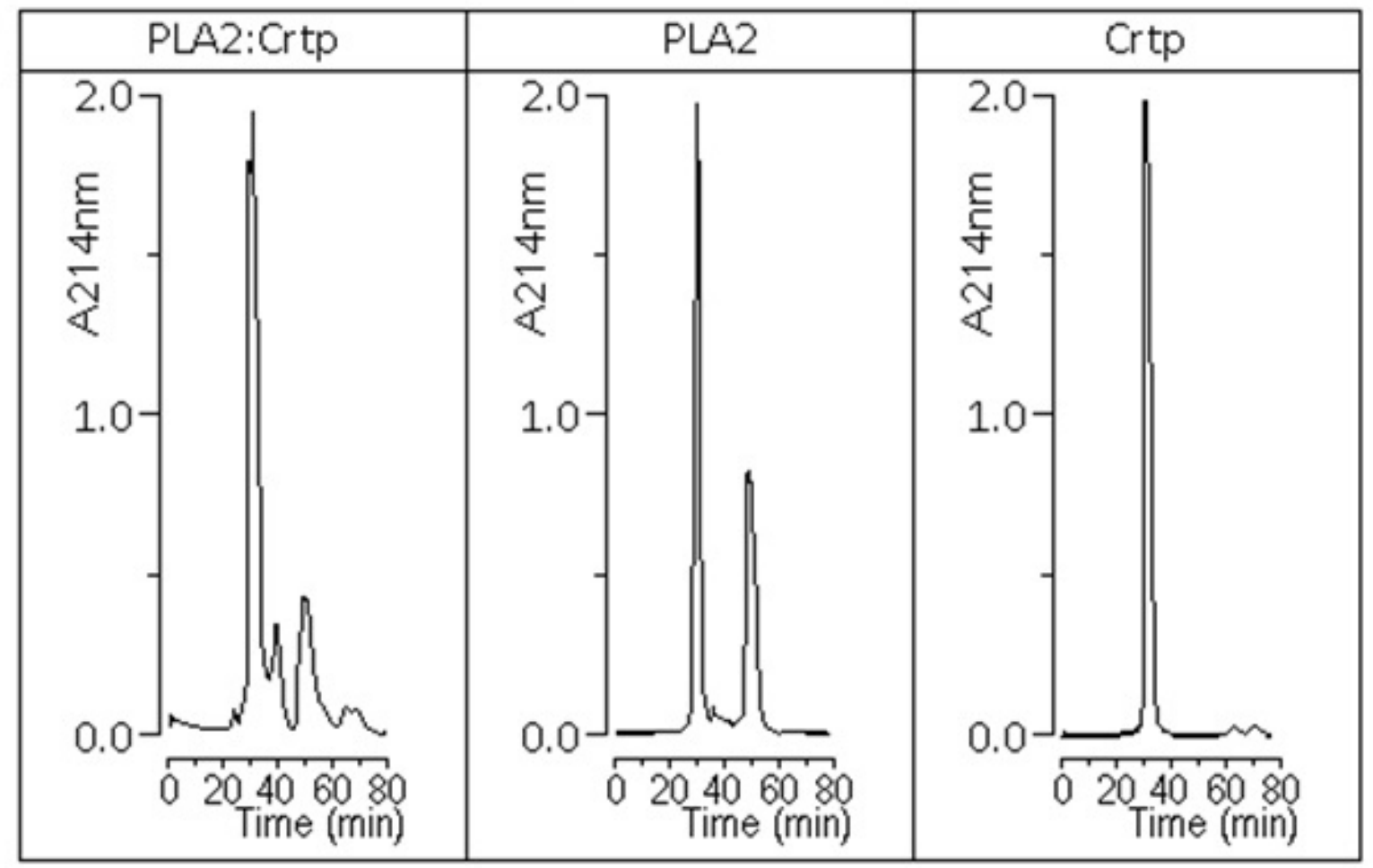

Figure 2. (A) The mass spectrometry profile of the crotoxin purified by fractionation of whole venom. In this profile, we observed molecular masses of 9643.0 and 14654.3 Da, which were identified as crotapotin (Crpt) and phospholipase $\mathrm{A}_{2}\left(\mathrm{sPLA}_{2}\right)$. Crotoxin is a self-association between sPLA $\mathrm{A}_{2}$ and $\mathrm{Crpt}$, which corresponds to the peak of $25562.6 \mathrm{Da}$ in the MS profile. (B) The results from the molecular size exclusion chromatography showed that $\mathrm{SPLA}_{2}$ formed stable homodimers in solution, thus we also identified a possible dimer of $\mathrm{SPLA}_{2}$ in the MS profile (29308.6 Da). 

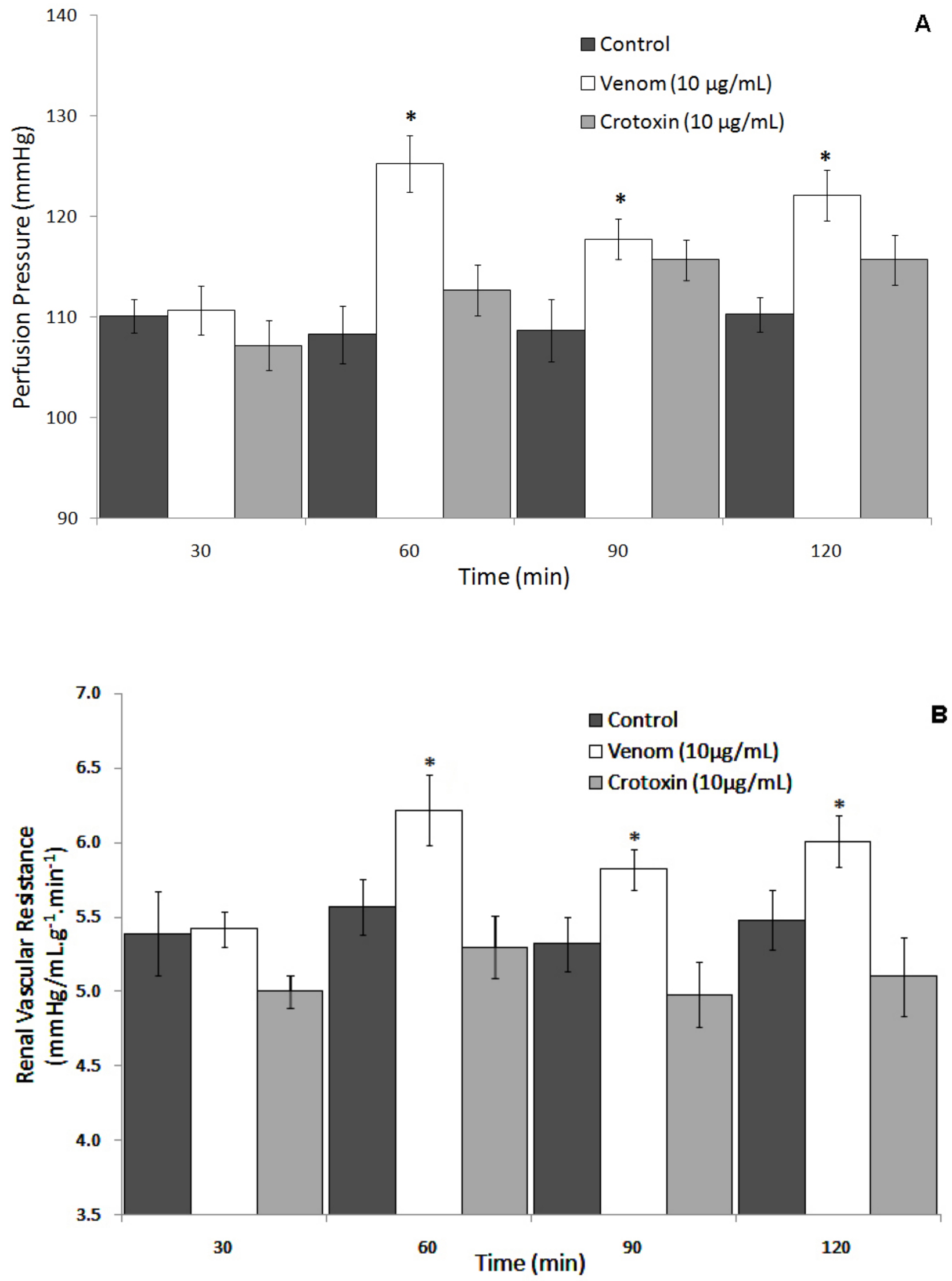

Figure 3. Effects of $C$. d. cumanensis venom $(10 \mu \mathrm{g} / \mathrm{mL})$ and crotoxin $(10 \mu \mathrm{g} / \mathrm{mL})$ on $(A)$ perfusion pressure $(\mathrm{PP})$ and $(\mathrm{B})$ renal vascular resistance (RVR).The results are expressed as mean $\pm \mathrm{SEM}, \mathrm{ANOVA}$, Bonferroni post-test, ${ }^{*} p<0.05$, compared to the corresponding control group. 

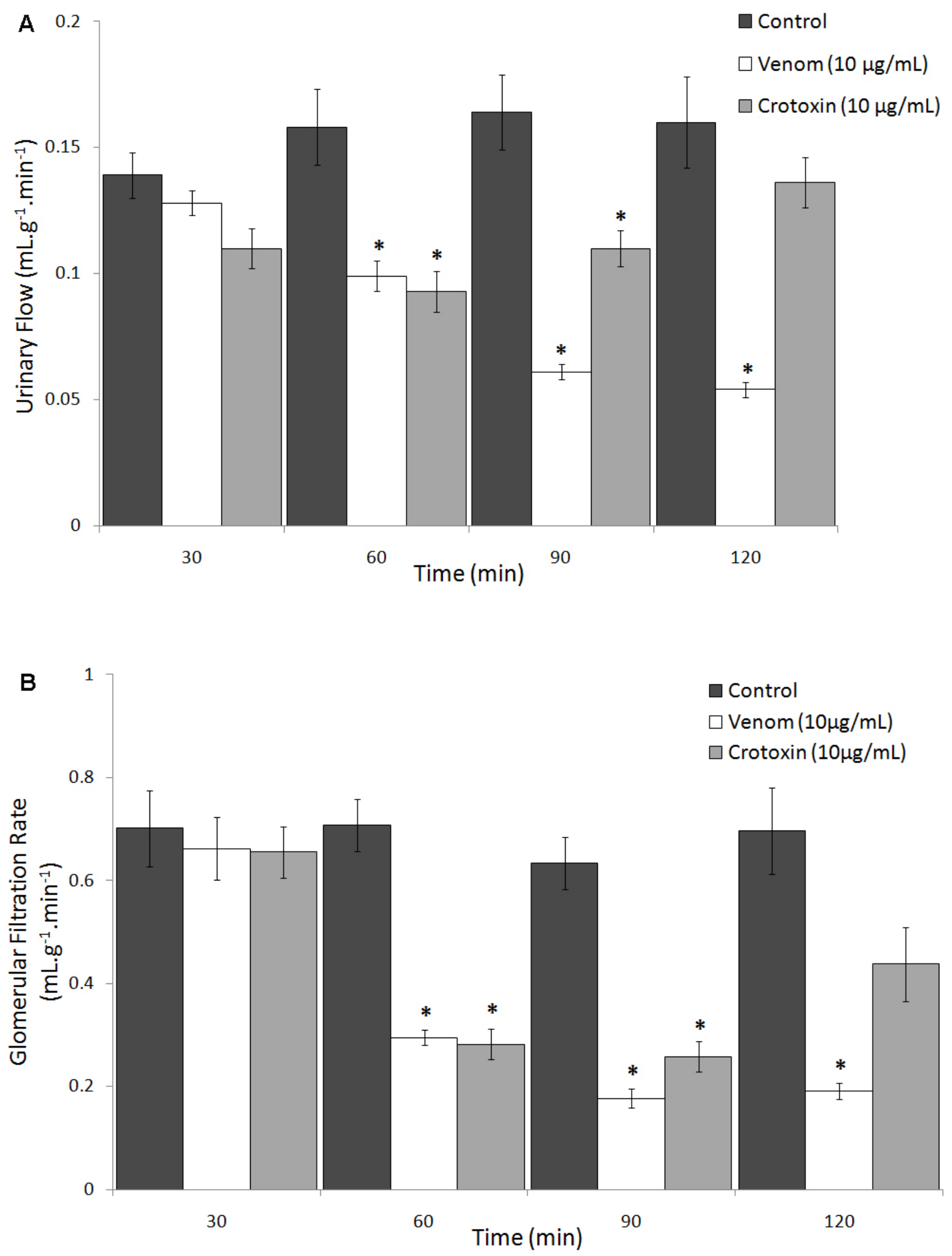

Figure 4. Effects of $C$. d. cumanensis venom $(10 \mu \mathrm{g} / \mathrm{mL})$ and crotoxin $(10 \mu \mathrm{g} / \mathrm{mL})$ on (A) urinary flow (UF) and (B) glomerular filtration rate (GFR).The results are expressed as mean \pm SEM, ANOVA, Bonferroni post-test, ${ }^{*} p<0.05$, compared to the corresponding control group. 
Table 1. Effects of Crotalus durissus cumanensis venom and crotoxin on electrolyte transport in isolated kidney

\begin{tabular}{c|c|c|c|c}
\hline $\begin{array}{c}\text { Renal parameters } \\
\text { \%TNa }\end{array}$ & 30 minutes & 60 minutes & 90 minutes & 120 minutes \\
\hline Control & $81.94 \pm 1.24$ & $81.11 \pm 1.52$ & $79.26 \pm 0.90$ & $79.76 \pm 0.56$ \\
\hline Venom & $80.89 \pm 2.15$ & $69.16 \pm 1.78^{*}$ & $64.16 \pm 2.25^{*}$ & $71.70 \pm 1.15^{*}$ \\
\hline Crotoxin & $88.60 \pm 0.73$ & $69.89 \pm 1.10^{*}$ & $59.29 \pm 2.34^{*}$ & $59.03 \pm 2.72^{*}$ \\
\hline \%TK & & \\
\hline Control & $72.14 \pm 2.90$ & $73.66 \pm 2.39$ & $73.15 \pm 3.26$ & $74.46 \pm 3.40$ \\
\hline Venom & $73.40 \pm 2.68$ & $59.66 \pm 2.52^{*}$ & $58.24 \pm 2.28^{*}$ & $70.66 \pm 0.86$ \\
\hline Crotoxin $^{*}$ & $82.40 \pm 1.31$ & $58.58 \pm 1.47^{*}$ & $45.15 \pm 3.34^{*}$ & $48.58 \pm 3.75^{*}$ \\
\hline \%TCl & & \\
\hline Control & $79.90 \pm 1.03$ & $81.25 \pm 2.44$ & $77.32 \pm 2.22$ & $78.53 \pm 2.33$ \\
\hline Venom & $79.29 \pm 2.32$ & $66.71 \pm 1.96^{*}$ & $62.32 \pm 2.29^{*}$ & $70.74 \pm 1.07^{*}$ \\
\hline Crotoxin & $86.70 \pm 0.77$ & $66.39 \pm 1.29^{*}$ & $55.84 \pm 2.67^{*}$ & $56.21 \pm 2.24^{*}$ \\
\hline
\end{tabular}

The results are expressed as mean \pm SEM, $p<0.05$

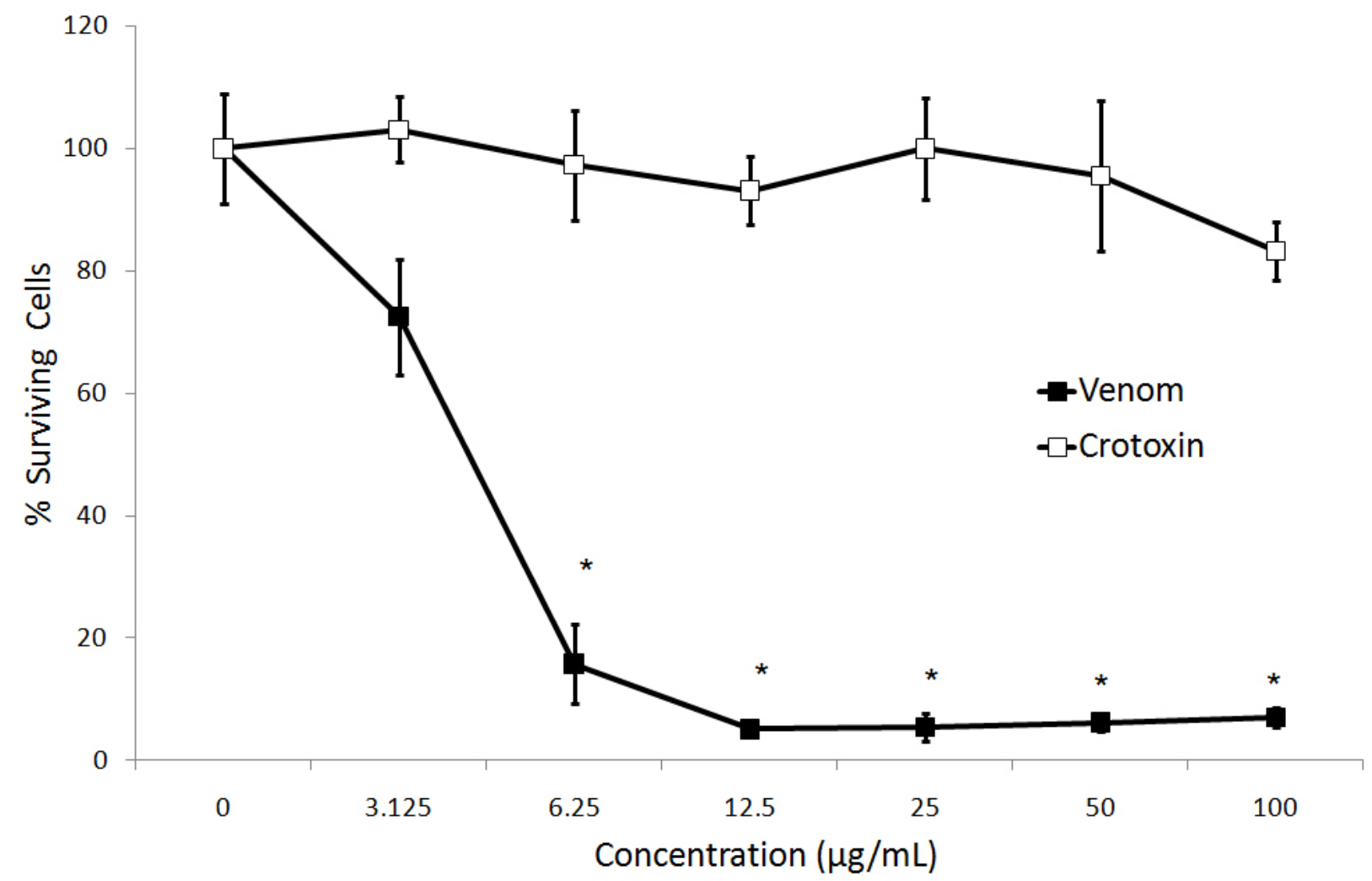

Figure 5. Cytotoxic effect of $C$. $d$. cumanensis venom (black squares) and crotoxin (white squares) - both applied in the concentration range of $3.12-100 \mu \mathrm{g} / \mathrm{mL}$ - on MDCK cells by the MTT method. Data are expressed as means \pm SEM, ANOVA, Dunnett's post-test, ${ }^{*} p<0.05$, compared to the corresponding control group. 

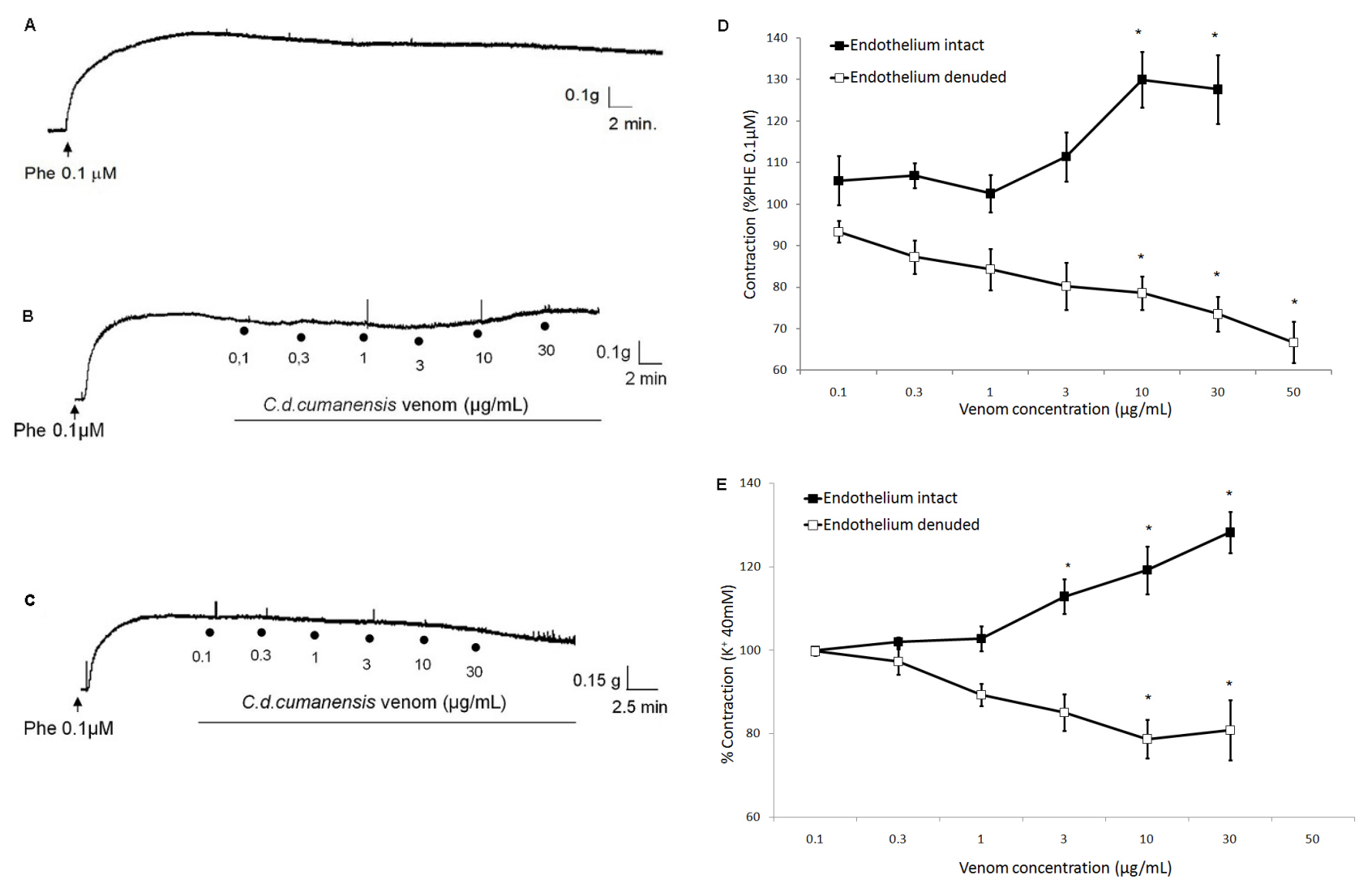

Figure 6. (A) Typical trace illustrating the timed control of a sustained PHE-induced contraction in aortic rings maintained in the presence of $0.1 \mu \mathrm{M}$ PHE for 55 minutes. Typical traces of a concentration-response curve of the $C$. $d$. cumanensis venom on (B) endothelium-intact or (C) endothelium-denuded aortic rings pre-contracted with $0.1 \mu \mathrm{M}$ PHE. Note that the vascular relaxation induced by $1 \mu \mathrm{M} \mathrm{ACh}$ added during the steady state of a PHE-elicited contraction was observed only in endothelium-intact preparations. (D) Concentration-response curve depicting the effects of $C$. $d$. cumanensis venom on isolated aortic rings in the presence $(\bullet: 0.1-30 \mu \mathrm{g} / \mathrm{mL})$ and absence $(\Delta: 0.1-50 \mu \mathrm{g} / \mathrm{mL})$ of endothelium, and on phenylephrine-induced contraction $(\mathrm{PHE}, 1 \mu \mathrm{M})$. (E)Concentration-responsecurvedepictingtheeffects of C. $d$. cumanensis venom on isolated aortic rings in the presence $(\bullet: 0.1-30 \mu \mathrm{g} / \mathrm{mL})$ and absence $(\Delta: 0.1-50 \mu \mathrm{g} / \mathrm{mL})$ of endothelium, and on potassium-induced contraction $\left(\mathrm{K}^{+}, 40 \mathrm{mM}\right)$. Data are expressed as means $\pm \mathrm{SEM}$, one-way ANOVA, Holm-Sidak post-test, ${ }^{*} p<0.01$, compared with corresponding baseline values.

60 minutes, which remained elevated for up to 120 minutes of perfusion. Conversely, the urinary flow (UF, Figure $4-\mathrm{A}$ ) and the glomerular filtration rate (GFR, Figure $4-\mathrm{A}$ ) values were gradually, but significantly $(p<0.05$, Bonferroni) reduced at 60 minutes, an effect that lasted throughout 120 minutes of perfusion. The venom was also able to decrease sodium $\left(\% \mathrm{TNa}^{+}\right)$, chloride $\left(\% \mathrm{TCl}^{-}\right)$and potassium $\left(\% \mathrm{TK}^{+}\right)$tubular transport (Table 1$)$.

Perfusion of the isolated kidney with crotoxin $(10 \mu \mathrm{g} / \mathrm{mL}, \mathrm{n}=5)$ produced no significant changes in either PP (Figure 3 - A) or RVR (Figure 3 B) values. On the other hand, the UF (Figure 4 - A) and GFR (Figure 4 - B) values decreased significantly $(p<0.05$, Bonferroni) only at 60 and
90 minutes of perfusion. Crotoxin significantly reduced all ionic tubular transport throughout the period from 60 to 120 minutes of kidney perfusion (Table 1).

\section{Cytotoxic Effects of CDCmV and Crotoxin on MDCK Cells}

Cytotoxic effects of $\mathrm{CDCmV}$ and crotoxin on MDCK cells were analyzed by the MTT method. Following 24-hour exposure, CDCmV promoted a concentration-dependent cytotoxic effect (Figure 5) with an $\mathrm{IC}_{50}$ value of $5.38 \mu \mathrm{g} /$ $\mathrm{mL}$. However, no significant reduction in cell viability was observed after crotoxin treatment (squares). 


\section{Effects of CDCmV and Crotoxin on Isolated Rat Aortic Rings}

In endothelium-intact rings maintained under basal tension, the cumulative addition of $\mathrm{CDCmV}(0.1-30 \mu \mathrm{g} / \mathrm{mL})$ produced no effect on the aortic resting tonus. On the other hand, aortic rings produced a submaximal contraction when they were stimulated with PHE $(0.1 \mu \mathrm{M})$. After approximately 15 minutes of PHE addition, aortic tonus was increased to a value equivalent to 256.8 $\pm 41.9 \mathrm{mg}(\mathrm{n}=6)$, which remained stable for a period of 40 minutes without significant changes in force $(99.1 \pm 3.2 \%$ of the control value, $\mathrm{n}=6$, $p>0.05$, ANOVA, Holm-Sidak post-test) (Figure $6-\mathrm{A})$.

In endothelium-intact rings in a steady state of PHE-induced contraction, addition of $\mathrm{CDCmV}$ (0.1-30 $\mu \mathrm{g} / \mathrm{mL})$ significantly increased this response to $130.0 \pm 6.6 \%$ of the contraction obtained in the absence of venom $(p<0.05$, ANOVA followed by Holm-Sidak post-test, $\mathrm{n}=$ 4), a value obtained at $10 \mu \mathrm{g} / \mathrm{mL}$ (Figure $6-\mathrm{B}$ and D). In contrast, in endothelium-denuded aortic rings, the venom $(0.1-50 \mu \mathrm{g} / \mathrm{mL})$ slightly but significantly relaxed $(p<0.01$, ANOVA, HolmSidak post-test) the PHE-induced vasoconstrictor responses down to $66.7 \pm 4.9 \%(n=4)$ of the control contraction (Figure $6-\mathrm{C}$ and $\mathrm{D}$ ).

When the aortic rings were contracted with a high concentration of potassium $(40 \mathrm{mM})$, the effects observed after addition of the venom showed a profile similar to that presented by PHE-induced contractions. In brief, a significant increase in the potassium-induced contraction was observed in endothelium-intact aortic rings, which reached a value of $128.23 \pm 4.9 \%$ (at $30 \mu \mathrm{g}$ / $\mathrm{mL}, \mathrm{n}=6$ ). In contrast, vasorelaxant effects were observed in endothelium- denuded preparations, although this effect was significant $(p<0.01$, ANOVA, Holm-Sidak post-test) only at $50 \mu \mathrm{g}$ of the venom per $\mathrm{mL}$. Under these conditions, the potassium-induced contraction was reduced to $70.9 \pm 4.7 \%(n=4)$ of the control value (Figure $6-\mathrm{E})$. Under control conditions, the potassiuminduced contractions persisted for 40 minutes without significant changes in force $(95.3 \pm 6.3 \%$ of the control value $n=6, p>0.01$, ANOVA).

However, cumulative addition of crotoxin (0.1-30 $\mu \mathrm{g} / \mathrm{mL})$ produced no significant effects on the contractions provoked by either PHE $(0.1 \mu \mathrm{M}, \mathrm{n}=4)$ or potassium $(40 \mathrm{mM}, \mathrm{n}=4)$ in endothelium-intact aortic rings. Additionally, in these preparations maintained under $\mathrm{Ca}^{2+}$ free conditions, PHE $(0.1 \mu \mathrm{M})$ induced a small and unsustained contraction measuring $22.49 \pm$ $3.10 \%(n=4)$ of that obtained in normal $\mathrm{Ca}^{2+}$ containing solution. This response was not significantly altered ( $p>0.05$, paired Student's t-test) in the presence of $30 \mu \mathrm{g} / \mathrm{mL} \mathrm{CDCmV}$ $(17.36 \pm 3.06 \%, n=4)$.

\section{DISCUSSION}

In the present work, the renal and vascular effects of thevenom obtained from C.d.cumanensis and its isolated fraction, crotoxin, were evaluated. Toxicological and pharmacological approaches using these animal toxins are important because the genus Crotalus is responsible for the most severe ophidian accidents in Brazil, characterized by a high mortality level attributed mainly to the development of acute renal failure $(3,26)$. Although it is well known that Crotalus venom is able to induce neurotoxicity, coagulation disorders, systemic myotoxicity and acute renal failure, to date no reports have described the effects of the CDCmV on the renal function or the vascular smooth muscle contractility $(1,5,6)$.

Our data show that both $\mathrm{CDCmV}$ and its fraction, crotoxin, are biologically active by the methods used in this work, which have classically been considered reliable for evaluation of kidney function parameters. The functional viability of the isolated perfused rat kidney model remained stable over the 120 minutes for perfusion of this organ. Our results revealed that $\mathrm{CDCmV}$ elevated both PP and RVR but diminished the GFR, UF and $\% \mathrm{TNa}^{+}, \% \mathrm{TCl}^{-}$and $\% \mathrm{TK}^{+}$.

These results differed from the renal effects induced by Crotalus durissus cascavella venom, which increased both PP and UF, and decreased GFR in perfused isolated rat kidneys (26). Infusion of whole venom from Crotalus durissus terrificus caused no alteration in the PP, but augmented GFR and UF (27). On the other hand, Crotalus durissus collilineatus venom reduced all renal parameters, namely PP, RVR, UF, and GFR (28). Taken together, these results corroborate the existence of intraspecific variation in the biological effects induced by crotalic venoms (2).

The effects of CDCmV on PP and RVR are probably related to a putative vasoconstrictor effect of the venom that leads to reduction of the GFR via a decrease in a driving force that 
favors ultrafiltration. In order to corroborate this hypothesis, experiments were performed on isolated rat aortic ring preparations. We showed that this venom did not contract aortic rings maintained under basal tonus, but it promoted a further contractile response when aortic rings had been previously stimulated with either PHE or potassium. Interestingly, the potentiating effect of the venom was observed only in endothelium-intact preparations, whereas a slight myorelaxation occurred in preparations without functional epithelium.

Thus, it is reasonable to suggest that the renal effects induced by the CDCmV may be due to its influence on the endothelium's ability to release factors that can alter the contractile behavior of vascular smooth muscle. Two general hypotheses should be considered to explain this effect: the venom may induce a diminished release of an inhibitory endothelial factor, such as nitric oxide (NO) or endothelium-derived hyperpolarizing factors (EDHF); or the venom may promote the endothelial release of a vasoconstrictor factor, for example, endothelin. As a matter of fact, we have previously demonstrated that renal effects promoted by Bothrops moojeni myotoxin-I were due to release of renal endothelin (29). Furthermore, vasoconstrictor peptides have been found in some viper venoms including the inhibitory peptides sarafotoxin and bradykinin (30). However, further experiments will be necessary to elucidate the underlying mechanisms involved and, finally, whether the vascular effects are significant in either renal vasculature or even in vivo.

A candidate substance that may be involved in the mediation of $\mathrm{CDCmV}$-induced effects is crotoxin, the main toxin found in the venom of South American rattlesnakes, which is responsible for its nephrotoxic effects $(13,14)$. Crotoxin consists of a reversible protein complex composed of two non-identical sub-units, a basic phospholipase $\mathrm{A}_{2}\left(\mathrm{sPLA}_{2}\right)$ and an acidic nonenzymatic component called crotapotin (31). The crotapotin component is thought to act as a chaperone protein for $\mathrm{PLA}_{2}$ by increasing the biological activities of this enzyme (32). Interestingly, Crpt possesses anti-inflammatory activity in vivo, possibly because it interacts with extracellular $\mathrm{PLA}_{2}$ generated during the inflammatory process (33). There are several crotoxin isoforms that may result from a random association between PLA $_{2}$ and Crpt (34). This multiplicity and diversity of crotoxin isoforms appear to result from either a post-translational modification of a unique precursor of crotoxin or expression of different mRNA (35).

In addition, in vitro combinations of Crpt isoform with sPLA 2 isoform yielded two crotoxin complex types, one with high enzymatic activity and the other with high neurotoxicity. Isolated sPLA $_{2}$, as well as isolated Crpt, may induce biological activities by themselves, without the association between the molecules, as previously demonstrated by de Oliveira et al. (20), Toyama et al. (18) and Nogueira et al. (36). Moreover, in vitro studies carried out by HernandezOliveira et al. (37) and Toyama et al. (38) have shown - by means of enzymatic, biological or pharmacological methods - that Crpt exerts important modulatory effects on enzymatic

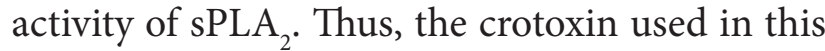
work was composed exclusively of PLA $\mathrm{P}_{2}$ and Crpt isoforms, and this fraction only partially reproduced the effects presented by the whole venom in the present study.

The differences between the effects elicited by crotoxin and those produced by the whole venom were pronounced. Although both the $\mathrm{CDCmV}$ and crotoxin had reduced the GFR and UF, only the whole venom increased the PP and the RVR. Additionally, crotoxin decreased the tubular transport of all the electrolytes studied. Moreover, crotoxin did not show any potentiating effects on the contractile response induced by PHE or potassium in aortic rings. Thus, the effects observed in the case of the whole venom may not be fully attributable to the presence of crotoxin alone, and they likely result from the presence of other vasoactive substances within the venom.

The observed effects of CDCmV may be due to its toxic actions on the renal and vascular smooth muscle cells. However, it is noteworthy that the effects of the crude venom were dependent on the endothelial integrity and did not change the transient contraction induced by PHE in $\mathrm{Ca}^{2+}$-free medium, indicating that its actions on vascular tissue may have been more specific than a simple toxic influence. The cytotoxicity induced by the $\mathrm{CDCmV}$ in renal tubular cells corroborates the hypothesis of a toxic effect. A cytotoxic activity exerted by the whole venom was expressed as a reduction of the cellular viability, an effect that may contribute to the decreased ability of the 
tubular cells to produce ionic transport. Similar effects have been produced by $C$. vegrandis venom on renal cells cultured from mouse renal cortex (1). A similar cytotoxic effect of the venom obtained from $B$. moojeni on MDCK cells was also reported (39). On the other hand, crotoxin presented no significant changes in cell viability in the concentration range herein studied. Based on these results of the present study, we can suggest that $\mathrm{CDCmV}$ must contain several different toxins that could act either individually or synergistically. It is important to highlight that the ontogenic and paedomorphic variations in venom composition of Crotalus durissus subspecies, including $C . d$. cumanensis, are considerable and may cause important variations in the biological effects of individual venoms (40, 41).

In conclusion, $\mathrm{CDCmV}$ is toxic to kidney cells. It alters such renal function parameters as the glomerular filtration rate, renal vascular resistance and tubular transport. The actions induced by $\mathrm{CDCmV}$ also include endotheliumdependent vasoactive properties. The observed $\mathrm{CDCmV}$ effects may be only partially attributable to its fraction Crtx.

\section{ACKNOWLEDGEMENTS}

The authors wish to thank Dr. Saad Lahlou for valuable scientific comments and language review, and two Brazilian agencies, The National Council for Scientific and Technological Development $(\mathrm{CNPq})$ and The Cearense Foundation for Supporting Scientific and Technological Development (FUNCAP), for their financial support.

\section{COPYRIGHT}

(c) CEVAP 2011

\section{SUBMISSION STATUS}

Received: March 21, 2011.

Accepted: June 7, 2011.

Abstract published online: June 14, 2011.

Full paper published online: August 31, 2011.

\section{CONFLICTS OF INTEREST}

There is no conflict.

\section{FINANCIAL SOURCE}

The National Council for Scientific and Technological Development $(\mathrm{CNPq})$ and The
Cearense Foundation for Supporting Scientific and Technological Development (FUNCAP) provided the financial grants.

\section{ETHICS COMMITTEE APPROVAL}

The present study was approved by the Ethics Committee on Animal Research of the Federal University of Ceará (protocol n. 68/08).

\section{CORRESPONDENCE TO}

ALICE MARIA COSTA MARTINS, Departamento de Análises Clínicas e Toxicológicas, Faculdade de Farmácia, Universidade Federal do Ceará, Rua Capitão Francisco Pedro, 1210, Fortaleza, CE, 60.420-970, Brasil. Phone: +55 853366 8263. Fax: +55 853366 8292. Email: martinsalice@gmail.com.

\section{REFERENCES}

1. Girón ME, Aguilar I, Romero L, Sánchez EE, Pérez JC, Rodriguez-Acosta A. A low-cost method to test cytotoxic effects of Crotalus vegrandis (serpentes: Viperidae) venom on kidney cell cultures. Rev Inst Med Trop São Paulo. 2005; 47(3):147-52.

2. Santoro ML, Sousa-e-Silva MC, Gonçalves LR, Almeida-Santos SM, Cardoso DF, Laporta-Ferreira IL, et al. Comparison of the biological activities in venoms from three subspecies of the South American rattlesnake (Crotalus durissus terrificus, C. durissus cascavella and C. durissus collilineatus). Compar Biochem Physiol Part C.1999;122(1):61-73.

3. Rangel-Santos A, Dos-Santos EC. Lopes-Ferreira M, Lima C, Cardoso DF, Mota I. A comparative study of biological activities of crotoxin and $\mathrm{CB}$ fraction of venoms from Crotalus durissus terrificus, Crotalus durissus cascavella and Crotalus durissus collilineatus. Toxicon. 2004;43(7):801-10.

4. Sitprija V, Chaiyabutr N. Nephrotoxicity in snakes envenomation. J Nat Toxins.1999;8(2):271-7.

5. Aguilar I, Guerrero B, Maria Salazar A, Girón ME, Pérez JC, SánchezEE, Rodríguez-Acosta A. Individualvenom variability in South American rattlesnake Crotalus durissus cumanensis. Toxicon.2007;50(2):214-24.

6. Hernández M, Scannone H, Finol HJ, Pineda ME, Fernández I, Vargas AM, et al. Alterations in the ultrastructural of cardiac autonomic nervous system triggered by crotoxin from rattlesnake (Crotalus durissus cumanensis) venom. Exp Toxicol Pathol. 2007;59(2):129-37.

7. Joseph R, Pahari S, Hodgson WC, Kini RM. Hypotensive agents from snake venoms. Curr Drug Targets Cardiovasc Haematol Disord. 2004;4(4):43759.

8. Yamazaki Y, Morita T. Snake venom components affecting blood coagulation and vascular system: structural similarities and marked diversity. Curr Pharm Des. 2007; 13(28):2872-86. 
9. Evangelista JS, Martins AMC, Nascimento NRF, Sousa CM, Alves RS, Toyama DO. Renal and vascular effects of the natriuretic peptide isolated from Crotalus durissus cascavella venom. Toxicon. 2008;52(7):737-44.

10. Ponce-Soto LA, Martins-de-Souza D, Novello JC, Marangoni S. Structural and biological characterization of two crotamine isoforms IV-2 and IV-3 isolated from the Crotalus durissus cumanensis venom. Protein J. 2007;26(8):533-40.

11. Barraviera B, Lomonte B, Tarkowski A, Hanson LA, Meira DA. Acute phase reactions including cytokins in patients bitten by Bothrops spp. and Crotalus durissus terrificus in Brazil. J Venom Anim Toxins. 1995;1(1):11-22.

12. Soares AM, Mancin AC, Cecchini AL, Arantes EC, França SC, Gutiérrez JM, et al. Effects of chemical modifications of crotoxin $\mathrm{B}$, the phospholipase $\mathrm{A}_{2}$ subunit of crotoxin from Crotalus durissus terrificus snake venom, on its enzymatic and pharmacological activities. Int J Biochem Cell Biol. 2001;33(9):877-88.

13. Ponce-Soto LA, Toyama MH, Hyslop S, Novello JC, Marangoni S. Isolation and preliminary enzymatic characterization of a novel PLA from Crotalus durissus collilineatus venom. J Protein Chem. 2002;21(3):131-6.

14. Romero-Vargas FF, Ponce-Soto LA, Martins-deSouza D, Marangoni S. Biological and biochemical characterization of two new PLA 2 isoforms Cdc-9 and Cdc-10 from Crotalus durissus cumanensis snake venom. Comp Biochem Physiol C Toxicol Pharmacol. 2010;151(1):66-74.

15. Da Silva M, Lucena S, Aguilar I, Rodriguez-Acota A, Salazar AM, Sánchez E, et al. Anti-platelet effect of cumanastatin 1, a desintegrin isolated from venom of South American Crotalus rattlesnake. Tromb Res. 2009;123(5):731-9.

16. Yoshida-Kanashiro E, Navarrete LF, RodriguezAcosta A. On the unsual hemorrhagic and necrotic activities caused by the rattlesnake (Crotalus durissus cumanensis) in a Venezuelan patient. Rev Cubana Med Trop. 2003;55(1):38-40.

17. Diz Filho EBS. Caracterização estrutural e farmacológica de $\mathrm{PLA}_{2}$ isoladas do veneno Crotalus durissus ruruima e Crotalus durissus cumanensis. Mestrado em Biologia Funcional e Molecular Bioquímica - Universidade Estadual de Campinas, São Paulo, 2007.

18. Toyama MH, de Oliveira DG, Beriam LO, Novello JC, Rodrigues-Simioni L, Marangoni S. Structural, enzymatic and biological properties of new PLA(2) isoform from Crotalus durissus terrificus venom. Toxicon. 2003;41(8):1033-8.

19. Toyama MH, Carneiro EM, Marangoni S, Barbosa RL, Corso G, Boschero AC. Biochemical characterization of two crotamine isoforms isolated by a single step RP-HPLC from Crotalus durissus terrificus (South American rattlesnake) venom and their action on insulin secretion by pancreatic islets. Biochim Biophys Acta. 2000;1474(1):56-60.

20. de Oliveira DG, Toyama MH, Martins AM, Havt A, Nobre AC, Marangoni S, et al. Structural and biological characterization of a crotapotin isoform isolated from Crotalus durissus cascavella venom. Toxicon. 2003;42(1):53-62.

21. Bowman RH. Gluconeogenesis in the perfused rat kidney. J Biol Chem. 1970; 245:1604-12.

22. Walser M, Davidson DG, Orloffs J. The renal clearance of alkali-stable inulin. J Clin Invest. 1955;34(10):15203.

23. Martinez-Maldonado M, Opava-Stitzer R. Free water clearance curves during saline, mannitol, glucose and urea diuresis in the rat. J Physiol. 1978;280:487-97.

24. Liu Y, Peterson DA, Kimura H, Schubert D. Mechanism of cellular 3-(4,5-dimethylethiozil2-yl)2,5-diphenyltetrazolium bromide (MTT) reduction. J Neurochem.1997;69(2):581-93.

25. Furchgott RF, Zawadzki JV. The obligatory role of endothelial cells in the relaxation of arterial smooth muscle by acetylcholine. Nature.1980;228(5789):373-6.

26. Martins AM, Monteiro HS, Júnior EO, Menezes DB, Fonteles MC. Effects of Crotalus durissus casacavella venom in the isolated rat kidney. Toxicon. 1998;36(10):1441-50.

27. Monteiro HS, da Silva IM, Martins AM, Fonteles MC. Actions of Crotalus durissus terrificus venom and crotoxin on the isolated rat kidney. Br J Med Biol Res. 2001;34(10):1347-57.

28. Amora DN, Sousa TM, Martins AMC, Barbosa PS, Magalhães MR, Toyama MH, et al. Effects of Crotalus durissus collilineatus venom in the isolated rat kidney. Toxicon. 2006;47(3):260-4.

29. Barbosa PS, Martins AMC, Alves RS, Amora $\mathrm{DN}$, Martins RD, Toyama $\mathrm{MH}$, et al. The role of indomethacin and tezosentan on renal effects induced by Bothrops moojeni Lys49 myotoxin I. Toxicon. 2006;47(8):831-7.

30. Graham RL, Graham C, McClean S, Chen T, O'Rourke $\mathrm{M}$, Hirst $\mathrm{D}$, et al. Identification and functional analysis of a novel bradykinin inhibitory peptide in the venoms of New World Crotalinae pit vipers. Biochem Biophys Res Commun. 2005;338(3):1587-92.

31. Hendon RA, Fraenkel-Conrat H. Biological roles of the two components of crotoxin. Proc Natl Acad Sci USA. 1971;68(7):1560-3.

32. Habermann E, Breithaupt H. Mini-review. The crotoxin complex- an example of biochemical and pharmacological protein complementation. Toxicon.1978; 16(1):19-30.

33. Landucci EC, Antunes E, Donato JL, Faro R, Hyslop $S$, Marangoni S, et al. Inhibition of carregeenininduced rat paw edema by crotapotin, a polypeptide complexes with phospholipase $\mathrm{A}_{2}$. Br J Pharmacol. 1995;114(3):578-83.

34. Faure G, Guillaume JL, Camoin L, Saliou B, Bon C. Multiplicity of acidic subunit isoforms of crotoxin, the phospholipase $\mathrm{A}_{2}$ neurotoxin from Crotalus durissus terrificus venom, results from posttranslations. Biochemistry. 1991;30(32):8074-83.

35. Faure G, Choumet V, Bouchier C, Camoin L, Guillaume JL, Monegier B, et al. The origin of the diversity of crotoxin isoforms in the venom of Crotalus durissus terrificus. Eur J Biochem. 1994;223(1):161- 4. 
36. Nogueira TC, Ferreira F, Toyama MH, Stoppiglia LF, Marangoni S, Boschero AC, et al. Characterization of the insulinotropic action of a phospholipase $\mathrm{A}_{2}$ isolated from Crotalus durissus collilineatus rattlesnake venom on rat pancreatic islets. Toxicon. 2005;45(2):243-8.

37. Hernandez-Oliveira S, Toyama MH, Toyama DO, Marangoni S, Hyslop S, Rodrigues-Simioni L. Biochemical, pharmacological and structural characterization of a new PLA from Crotalus durissus terrificus (South American rattlesnake) venom. Protein J. 2005;24(4):233-42.

38. Toyama MH, Toyama DO, Joazeiro PD, Carneiro EM, Beriam LO, Marangoni LS, et al. Biological and structural characterization of a new PLA from the Crotalus durissus collilineatus venom. Protein J. 2005;24(2):103-12.
39. Collares-Buzato CB, De Paula, Le Sueur L, Da CruzHöfling MA. Impairment of the cell-to-matrix adhesion and cytotoxicity induced by Bothrops moojeni snake venom in cultured renal tubular epithelia. Toxicol Appl Pharmacol. 2002;181(2): 124-32.

40. Calvete JJ, Sanz L, Cid P, de la Torre P, Flores-Díaz M, Dos Santos MC, et al. Snake venomics of the Central American rattlesnake Crotalus simus and the South American Crotalus durissus complex points to neurotoxicity as an adaptive paedomorphic trend along Crotalus dispersal in South America. J Proteome Res. 2010;9(1):528-44.

41. Céspedes N, Castro F, Jiménez, Montealegre L, Castellanos A, Cañas CA, et al. Biochemical comparison of venoms from young Colombian Crotalus durissus cumanensis and their parents. J Venom Anim Toxins incl Trop Dis. 2010;16(2): 26884 . 